\title{
The Revised Posting of Workers Directive: Curbing or Ensuring Free Movement?
}

\author{
Piet Van Nuffel* and Sofia Afanasjeva**
}

\section{Introduction}

Free movement is one of the fundamental rights of EU citizens. While constituting the cornerstone of the internal market, free movement often stirs political controversy, in particular in those specific situations where the moving citizen is liable to be perceived as a threat to the welfare system of the host Member State. The obvious example is the situation of economically inactive persons that seek access to a host Member State on the basis of the free movement right of a family member. The case of the posting of workers demonstrates that controversy may also arise when economically active EU citizens rely on free movement rights to take up work in another Member State.

Workers who are "posted" remain employed by their employer in the home Member State and are sent abroad only temporarily. Their situation is therefore covered by the freedom to provide services, not the free movement of workers. ${ }^{1}$ Where such posted workers constitute cheaper work force than local workers, local undertakings and workforce may perceive such exercise of the free movement of services as unfair competition, or even as "social dumping". Regulating the increasing use of posted workers, a phenomenon that finds itself at the intersection of internal market and labour protection rules, has turned out to be politically sensitive. It was Jean-Claude Juncker who as candidate for President of the European Commission announced in

\footnotetext{
* Associate Professor, Institute for European Law, KU Leuven; Member of the Legal Service, European Commission. The author has been involved in the negotiations of the Revised Posting of Workers Directive as Member of Cabinet of Commissioner Thyssen. All views are personal.

** Trainee at the Cabinet of Marianne Thyssen, Commissioner for Employment, Social Affairs, Skills and Labour Mobility (2014-1019), currently working at the European Parliament. All views are personal.

1 See Court of Justice, judgment of 25 October 2001, case C-49/98, Finalarte, paras. 22-23.
} 
July 2014 before the European Parliament a "targeted review" of the Posting of Workers Directive ${ }^{2}$ (the "PoW Directive"), indicating that "the same work at the same place should be remunerated in the same manner". ${ }^{3}$ In March 2016, with the express support of several Member States and considering that with the enlargement of the Union the existing legal framework for posted workers was not suitable anymore, the European Commission presented its proposal for that review.

Being high on the political agenda of many Member States, it was no surprise that this proposal became the subject of much controversy. Witness to this is the fact that French President Macron turned posting of workers into an important selling point of his campaign for the 2017 presidential elections. Together with other Western European Member States, France has been facing wage competition from workers posted from Eastern European Member States with lower wage levels, leading to the perception of posting of workers as an issue that directly opposes East to West within the EU. It is therefore a success that the Commission's proposal led in spring 2018 to a widely supported political agreement on a revised PoW Directive. ${ }^{4}$

This contribution seeks to explain how this reform builds on the principles developed in the case law of the Court of Justice and eventually managed to upgrade the PoW Directive, which is based on the Treaty provisions on free movement of services, into an extended package of protective labour rules that nevertheless remains within the boundaries of internal market legislation. By prescribing Member States to what extent the exercise of free movement by foreign employers may be regulated, the rules on posting lay down a level playing field in which all workers receive the necessary protection. Given the tensions caused by the increased use of posted workers in certain Member States that considered introducing measures to protect their labour markets, this recent harmonisation of the rules on posting thus also contributed to preserving, and not merely limiting, free movement and the internal market.

2 Directive $96 / 71 /$ EC of the European Parliament and of the Council of 16 December 1996 concerning the posting of workers in the framework of the provision of services, OJ L 18, 21.1.1997, p. $1-6$.

3 Juncker, J-C (2014). A New Start for Europe: My Agenda for Jobs, Growth, Fairness and Democratic Change - Political Guidelines for the next European Commission - Opening Statement in the European Parliament, Strasbourg, p. 8, available at https://ec.europa.eu/commission/ sites/beta-political/files/juncker-political-guidelines-speech_en.pdf.

4 Directive (EU) 2018/957 of the European Parliament and of the Council of 28 June 2018 amending Directive $96 / 71 / \mathrm{EC}$ concerning the posting of workers in the framework of the provision of services, OJ L 173, 9.7.2018, p. 16-24. 


\section{Posting of Workers on European Labour Markets}

The term "posted workers" refers to workers who are legally employed by an undertaking established in one Member State (the sending or home Member State) and sent by that undertaking to another (receiving or host) Member State in order to carry out work in the host Member State. Typically, such work is carried out under a contract concluded by the sending undertaking for the provision of services in the host Member State. There may also be "intra-group posting", when an undertaking sends an employee to work in a subsidiary in another Member State. A third category of posted workers covers workers hired out by temporary work agencies established in the home Member State to a user undertaking in the host Member State. ${ }^{5}$

Since posted workers are sent abroad only temporarily, they do not intend to integrate in the labour market of the host Member State and thus remain covered by the social security system of the home Member State. Such workers will be issued a Portable Document A1 in their home Member State, confirming that contributions are paid for them in that Member State. ${ }^{6}$ Under the Regulation on the coordination of social security systems, a posted worker continues to be subject to the social security legislation of the home Member State if the duration of the work in the host Member State does not exceed 24 months. ${ }^{7}$ This prevents excessive administrative burden for posting undertakings and national authorities, which would otherwise have to change the applicable social security system for every worker performing services in another Member State for a limited time.

Posting of workers is an increasing phenomenon within the EU. Since 2011, the overall number of Portable Documents $A_{1}$ issued has almost doubled. ${ }^{8}$ Posted workers are highly concentrated in specific sectors, in particular the construction sector and, to a lesser extent, in education, health, social work services and business services. ${ }^{9}$ Still, only a limited number of Member States

5 See the categories of workers covered by the PoW Directive, Art. 1(3).

6 See the Decision No A 1 of 12 June 2009 the Administrative Commission for the Coordination of national social security systems. For that purpose, the Portable Document A1 has replaced since May 2010 the previous E1o1 document.

7 Art. 12(1) of Regulation (EC) No 883/2004 of the European Parliament and of the Council of 29 April 2004 on the coordination of social security systems, OJ L 166, 30.4.2004, p. 1-123.

8 De Wispelaere, F., De Smedt, L. and Pacolet, J - HIVA-KU Leuven (2019). Posting of workers - Report on A1 Portable Documents issued in 2018, European Commission, p. 9, available at: https://www.mobilelabour.eu/wp-content/uploads/2020/o2/PD-A1-report-Referenceyear-2018.pdf.

9 Ibid., p. 29. 
is affected by the presence of posted workers. In 2018, the pre-2004 Member States constituted the destination of 84 per cent of total postings ${ }^{10}$ : among the countries most affected are Germany, France and Belgium as top 3 receiving countries (which altogether received almost 50 per cent of total EU postings) and Germany, Poland and Spain as top sending countries. ${ }^{11}$ In particular, France, the Netherlands, Belgium, Sweden and Austria received far more workers posted than they sent. ${ }^{12}$ In several sectors, Member States face an increasing number of workers being posted from Central or Eastern Europe Member States with generally lower wage levels. Most postings from low-wage Member States occur in the industry sector, with 40 per cent to be situated in the construction sector. In that sector, Member States such as Luxembourg, Austria and Belgium have been experiencing a particularly large number of posted workers. ${ }^{13}$

Nevertheless, it must be stressed that looking at the general labour market, posting of workers remains a relatively limited phenomenon. It is estimated that around 0.8 per cent of the EU workforce can be considered to have been issued with a Portable Document A1, which is less than three million people. ${ }^{14}$ Not more than one third of these postings concern postings from low-wage to high-wage Member States. ${ }^{15}$ There are indeed also a large number of postings between high-wage Member States, in particular in the services sector. The average duration of the posting period is less than four months. ${ }^{16}$

\section{Introducing Workers' Protection through the Posting of Workers} Directive

It was the accession of Spain and Portugal in 1986 that started fuelling fears of large groups of workers from low-wage Member States entering the labour market of high-wage Member States after the Court of Justice had confirmed that companies could rely on the free movement of services to temporarily bring in their own workforce. ${ }^{17}$ The Court's case law on the balance to be struck

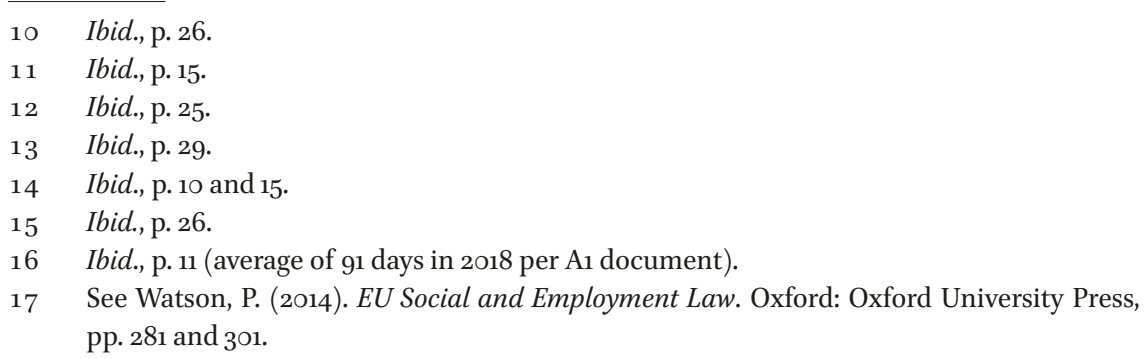


between free movement and workers' protection inspired the adoption of the PoW Directive in 1996 and also the Commission's 2016 proposal to revise that Directive.

\section{III.1 The Court of Justice and Workers' Protection in the Context of Cross-Border Services}

In the absence of legislative guidance, the Court of Justice was tasked with a challenging role. On the one hand, the free movement of services as a fundamental freedom had to be preserved against undue regulatory obstacles. On the other hand, the protection of workers and social policy goals had to be recognised as legitimate interests capable of justifying restrictions to that economic freedom. The Court could not escape the finding that measures imposed by a host Member State that put an obstacle to undertakings established in another Member State in their provision of services in the host Member State have to be qualified as "restrictions" to free movement. However, under the Court's established case law on free movement, such finding does not imply that any measures laid down by the host Member State to protect workers becomes subordinated to the objective of market liberalisation underpinning the Treaty provisions on free movement. Restrictions to free movement may indeed be justified provided that they apply without distinction to all undertakings operating in the host Member State and remain proportionate to the pursued objective. ${ }^{18}$

In a number of cases, the Court concluded that social legislation restricting the provision of services from other Member States went beyond what was necessary to safeguard workers' rights, for example, because service providers were required to pay social contributions for social benefits to which the undertakings already contributed in the home Member State. ${ }^{19}$ At the same time, however, the Court confirmed that a host Member State may invoke social policy objectives to impose requirements that effectively ensure workers' protection. Thus, the Court considered in Seco that the free movement of services does not prevent a host Member State from applying legislation or collective labour agreements setting minimum wages to be paid to any person employed, even temporarily, within its territory, irrespective of the Member

18 See Finalarte, cit., paras. 31-32; Court of Justice, judgment of 24 January 2002, case C-164/ 99, Portugaia Construções, para. 19; Court of Justice, judgment of 12 October 2004, case C-6o/o3, Wolff \& Müller, para. 34 .

19 See Court of Justice, judgment of 3 February 1982, joined cases $62 / 81$ and 63/81, Seco and Desquenne \& Giral, para. 9; Court of Justice, judgment of 28 March 1996, case C-272/94, Guiot, para. 22. 
State where the employer is established, and from enforcing such rules by appropriate means. ${ }^{20}$ In Rush Portuguesa the Court confirmed the host Member State's freedom to apply legislation protecting workers, without limiting it to minimum wages. ${ }^{21}$ Those rulings prompted the Commission to come up in 1991 with a proposal for legislation "to lay down a nucleus of mandatory rules for minimum protection to be observed in the host country". 22

\section{III.2 The Posting of Workers Directive Laying Down a Nucleus of Protective Rights}

The Commission's proposal of August 1991 acknowledged that a balance needed to be struck between opposing principles: free competition across the borders to realise the full potential of the internal market, even when the main comparative advantage of some Member States is a lower wage cost, and having Member States set minimum pay levels applicable to all workers on their territory to ensure a minimum standard of living. ${ }^{23}$ It led to an exhaustive ${ }^{24}$ list of rights set out in Article 3(1) of the PoW Directive, which not only aims at protecting the posted workers, but also at guaranteeing that the level of protection ensured by the PoW Directive does not render the cross-border provision of services too burdensome or costly for foreign undertakings. The "nucleus" of rights deals with those issues which are of immediate interest to the worker and the posting undertaking during the posting assignment, such as minimum rates of pay, including overtime pay, paid annual holidays, maximum work periods, and health, safety and hygiene at work. These terms and conditions have to be guaranteed by the posting undertaking based on the legal framework applicable in the host Member State. The list excludes provisions on dismissal and standards relating to the representation of workers, as those are not relevant for the short-term duration of the work provided in the host Member State.

The PoW Directive introduced that nucleus of mandatory rules for all posted workers, leaving the definition of a worker to be determined by the host

20 Seco and Desquenne \& Giral, cit., para. 14. See also Guiot, cit., para. 12; Court of Justice, judgment of 23 November 1999, joined cases C-369/96, Arblade, and C-376/96, Leloup, para. 43 .

21 Court of Justice, judgment of 27 March 199o, case C-113/89, Rush Portuguesa, para.18.

22 PoW Directive, recital 13.

23 Proposal of 1 August 1991 for a Council Directive concerning the posting of workers in the framework of the provision of services, сом(91) 230 final. Amended Proposal сом(93) 225 final was submitted in June 1993 .

24 Court of Justice, judgment of 18 December 2007, case C-341/05, Laval un Partneri, para. 80-81. See also infra section III.3. 
Member State's legislation. Since the nucleus of the protective rights is applied in accordance with the host Member State rules, it would indeed not have made sense to regulate situations for which no protection is provided under that Member State's law. The PoW Directive does not set any maximum period for the posting activities falling within its scope. Likewise, it does not define any minimum duration, although it contains an exemption for workers posted less than eight days for assembling or installing goods and also allows Member States to exempt posting activities which do not exceed one month or which concern "not significant work". The Court of Justice however indicated that there may be circumstances, with several and brief crossing of borders, where it could be disproportionate for a host Member State to apply its legislation on minimum wages. ${ }^{25}$ In the sector of international road transport, a host Member State can indeed be expected to require minimum wages only for posted workers having established a sufficient link with the territory of that Member State. ${ }^{26}$

The issue that stirred most debate in the adoption process of the PoW Directive, and continued to do so after its transposition, has been the application of the requirement to pay posted workers minimum rates of pay. The PoW Directive specifies that it is for the host Member State's law and practice to define the concept of minimum rates of pay (Article 3(1)), indicating that allowances specific to the posting must be considered part of the minimum wage, unless they are paid in reimbursement of expenditure actually incurred by workers, such as expenditure on travel, board and lodging (Article 3(7)). As the PoW Directive does not indicate what exactly falls under the notion of minimum rates of pay, it has been for the national courts to determine that notion on a case-by-case basis. When asked to clarify that notion, the Court of Justice held that it is for the host Member State's law to define the constituent elements of minimum rates of pay, while indicating that national legislation or collective agreements should not have the effect of impeding the freedom to

25 Court of Justice, judgment of 15 March 20o1, case C-165/98, Mazzoleni and ISA, paras. 30-39.

26 See rec. 10 of the Commission's 2016 Proposal (see infra fn. 63). Accordingly, the specific rules on which the negotiators from the European Parliament and the Council agreed on 12 December 2019 foresee that drivers are not considered 'posted' if they perform bilateral transport operations from the Member State of establishment to another State or are merely transiting through such other State. See Article 1 of the Directive laying down specific rules for the application of Directive 96/71/EC and Directive 2014/ $67 / \mathrm{EU}$, as adopted by the Council as its position in first reading on 7 April 2020 (ST $51122020)$. 
provide services. ${ }^{27}$ The notion of minimum wage does not include allowances or supplements, which the law or practice of the host Member State does not define as constituent elements of the minimum wage and which alter the relationship between the service provided by the worker and the consideration received in return. ${ }^{28}$

Further clarification on the notion of minimum wage resulted from the Finish case Sähköalojen ammattiliitto ${ }^{29}$ concerning a trade union in the electricity sector bringing pay claims assigned to it by workers posted to Finland by a Polish undertaking. Several allowances included in a collective agreement had not been taken into account by the Polish employer. The Court qualified the daily allowances imposed by the agreement as allowances specific to the posting within the meaning of Article 3(7) of the PoW Directive, as they intended to make up for the disadvantages entailed by the worker being removed from his usual working environment. ${ }^{30}$ Thus, these allowances had to be considered part of minimum wage and had to be paid to posted workers without discrimination. The same applied to travelling time compensation, applicable whenever a worker had to travel every day for more than one hour from his lodging to the place of work, provided that the posted workers were in such situation. ${ }^{31}$ However, other elements, like coverage for accommodation costs and meal vouchers were not considered constituent elements of pay, as they were paid to compensate for living costs actually incurred by workers during the posting assignment. ${ }^{32}$

\section{III.3 Continued Controversy in the Balance between Free Movement and Social Protection}

At the time of adoption of the PoW Directive, the Commission considered that legal framework fit for the purpose of ensuring a fair balance amongst the interests concerned by removing obstacles to the freedom to provide services

27 Court of Justice, judgment of 12 February 2015, case C-396/13, Sähköalojen ammattiliitto, para. 34 .

28 Court of Justice, judgment of 14 April 2005, case C-341/o2, Commission v. Germany, paras. $31-39$ (considering regularly paid " $13^{\text {th }}$ and 14 th months" supplements as elements of minimum rates of pay, but not quality bonuses or bonuses for dangerous and heavy work paid to workers when they are required to carry out additional work or work under certain conditions). See also Court of Justice, judgment of 7 November 2013, case C-522/12, Tevfik Isbir, paras. 40-44.

29 Sähköalojen ammattiliitto, cit.

$30 \quad$ Ibid., para. 49.

31 Ibid., paras. $53-57$.

$32 \quad$ Ibid., paras. $5^{8-63}$. 
and at the same time providing legal clarity on the nucleus of the working conditions applicable to posted workers. ${ }^{33}$ However, the subsequent enlargement from 15 to 25 and eventually 28 Member States brought enormous diversity to the Union, bringing together countries with very different wage levels and social security coverage.

At the same time, the Court of Justice had had to rule on several cases involving national legislation protecting workers, and some of these measures were found to be inconsistent with the Treaty provisions on free movement and/or the provisions of the PoW Directive. Most often, the proportionality test proved not to be fulfilled ${ }^{34}$ Various administrative requirements, such as requirements to obtain work permits for posted workers, were considered disproportionate as alternative measures were available that would be less restrictive to free movement, such as obligations to report beforehand on the presence of posted workers, the anticipated duration of their presence and the provision of services justifying the posting. ${ }^{35}$ The Court considered other measures justified for the proper enforcement of the posting rules, including requirements for posting undertakings to facilitate controls by retaining on the work site essential documents, such as the employment contract, pay-slips and time-sheets, as well as the obligation to have these documents available in the language of the host Member State. ${ }^{36}$

Importantly, the Court of Justice also recognised that a host Member State may not only invoke the objective of workers' protection, but also the objective to prevent unfair competition on the part of posting undertakings paying their workers at a rate less than the minimum rate of pay. ${ }^{37}$ The Court also

33 Proposal for a Council Directive Concerning the posting of workers in the framework of the provision of services, Сом(91) 230 final, p.14. See also Maslauskaite, K. (2014). Posted Workers in the EU: State of Play and Regulatory Evolution. Paris: Jacques Delors Institute, Policy Paper 107, available at http://www.institutdelors.eu/wp-content/uploads/2018/o1/ postedworkers-maslauskaite-ne-jdi-marı4.pdf?pdf=ok; Dhéret, C. and Ghimis, A. (2016). The Revision of the Posted Workers Directive: Towards a Sufficient Policy Adjustment? Brussels: European Policy Centre, available at http://www.epc.eu/documents/uploads/ pub_6475_revision_of_the_posted_workers_directive.pdf?doc_id=1726.

34 See also Syrpis, P. (2016). EU Secondary Legislation and its Impact on Derogations from Free Movement. In: Nic Shuibhne, Koutrakos and Syrpis, eds., Exceptions from EU Free Movement Law: Derogation, Justification and Proportionality. Oxford and Portland: Hart Publishing, pp. 278-296.

35 See, for example, Court of Justice, judgment of 21 October 2004, case C-445/03, Commission v. Luxembourg, para. 31; Court of Justice, judgment of 7 October 2010, case C-515/o8, dos Santos Palhota, paras. 51-6o.

36 Commission v. Germany, cit., para. 71.

37 Wolff \& Müller, cit., para. 41. To be noted that the PoW Directive, in recital 5, already referred to the transnational provision of services requiring "a climate of fair competition". 
made clear that in so far a host Member State applies measures pursuing an objective of public interest, such as minimum rates of pay, measures intended to facilitate posted workers to usefully assert their rights against their employer should equally be accepted. This is the case, for example, for provisions enabling, in case of contractors making use of a subcontractor, the subcontractor's workers to hold the first undertaking liable for payment of the minimum rate of pay. ${ }^{38}$

Although these rulings confirmed the Court's willingness to preserve workers' protection and fair competition when assessing national measures under the PoW Directive, full trust in the Court's willingness to give adequate weight to workers' rights became undermined by 2007 and 2008 case law on the protection of collective bargaining and collective action in a context of cross-border provision of services. It should be noted that in many Member States matters of pay, including minimum rates of pay, as well as other working conditions are traditionally determined by social partners through collective labour agreements. In its Article 3(1), the PoW Directive already provided that in the construction sector, an undertaking posting workers must not only apply the rights set out in the host Member State's legislation, but also those laid down by collective agreements that have been declared universally applicable. ${ }^{39}$ In addition, the increasing presence of workers posted by undertakings from low-wage Member States prompted trade unions to take collective action against such undertakings, amongst which the famous Laval case ${ }^{40}$ concerning a Latvian undertaking posting workers to Swedish construction sites. Swedish trade unions had initiated negotiations requiring Laval to pay its posted workers the Swedish usual hourly wage. The break-up of these negotiations lead to a blockage of the construction site, following which the dispute was brought to a Swedish court, which referred questions on the compatibility of the collective action with the freedom to provide services to the Court of Justice. Amongst others, the Court had to clarify whether the PoW Directive allows imposing conditions that do not result from universally applicable collective agreements and whether, more generally, other conditions can be imposed than the nucleus of protective rights set out in the PoW Directive.

On the first point, it was indicated above that Article 3(1) of the PoW Directive allows collective agreements that have been declared universally

38 Wolff \& Müller, cit., paras. 37-40.

39 Under Art. 3(1), this is the case for "the activities referred to in the Annex". The Annex clarifies that this concerns building work relating to the construction, repair, upkeep, alteration or demolition of buildings. 
applicable to be taken into account when imposing minimum rates of pay in the construction sector. Article 3(8) of the PoW Directive allows Member States to rely also on collective agreements in the absence of a system to declare such agreements universally applicable, provided that these agreements are de facto generally applicable to all undertakings in the industry concerned. The purpose of both provisions is to prevent posted workers from being made subject to collective agreements that local undertakings are not obliged to apply. However, the Swedish situation was rather particular in the sense that no legislation or collective agreements existed containing minimum rates of pay, but only a practice whereby management and labour set the applicable wage rates (not the minimum rates) by way of collective negotiations on a case-bycase basis, at the place of work. In the absence of any public or collectively agreed provision on which foreign service providers could have relied, the Court concluded that there was no question of minimum rates of pay determined in accordance with Article 3(1) and (8) of the PoW Directive. ${ }^{41}$ Since the collective action could not be justified by the PoW Directive, it had to be assessed in the light of the Treaty provision on free movement of services. In that context, the Court considered that the negotiations which the collective action sought to impose on Laval were not justified as this employer was already, pursuant to the PoW Directive, required to comply with a nucleus of mandatory rules and faced, in the absence of any transparent regulatory system, excessive difficulties to determine the additional obligations with which it was required to comply as regards pay. ${ }^{42}$

Second, the Court considered in Laval that by establishing the minimum protective rights that have to be respected by posting undertaking, Article 3(1) of the PoW Directive does not allow the host Member State to make the provision of services in its territory conditional on the observance of other terms and conditions. ${ }^{43}$ Some authors consider that the Court's ruling went against indications in the PoW Directive that the Directive does not prevent conditions which are more favourable to workers, ${ }^{44}$ arguing that the Court

41 Ibid., paras. 69-71. See also Feenstra, S. (2009). Detachering van werknemers in het kader van het verrichten van diensten - Het arbeidsrechtelijke kader - Richtlijn 96/71/EG. In: Jorens, ed., Handboek Europese detachering en vrij verkeer van diensten. Bruges: Die Keure, p. 268.

42 Laval un Partneri, cit., paras. 108-110.

43 Ibid., paras. 8o-81.

44 Art. 3(7) and recital 17 of PoW Directive indicate that the mandatory rules for minimum protection must not prevent the application of terms and conditions of employment, which are more favourable to workers. 
transformed into a 'ceiling' what was supposed to be a 'floor' 45 This alternative interpretation of the PoW Directive is however difficult to square with the PoW Directive's objective to create legal certainty on the rules that a host Member State may impose on foreign service providers. The level of protection which must be ensured to posted workers has indeed been limited to the protective rights set out in Article 3(1) of the PoW Directive, without prejudice to any further-going protection that the posting undertaking would accord them on its own volition or in accordance with the terms and conditions required under the law of the home Member State. ${ }^{46}$

Whereas both conclusions could thus arguably be derived from the PoW Directive's provisions, the Laval judgment was badly received in trade unions' circles. For a large part, this can be explained by the fact that the judgment was pronounced only one week after the judgment in the Viking case, ${ }^{47}$ where the Court equally considered collective action by a trade union to constitute a restriction of free movement that could not be justified by the objective of protecting workers' rights. In two subsequent judgments (Rüffert ${ }^{48}$ and Commission v Luxembourg), ${ }^{49}$ the Court also concluded that a host Member State's protective measures were not justified under the PoW Directive. ${ }^{50}$ In the light of the increasing posting of workers from low-wage Member States to high-wage Member States, the frustration of trade unions and other advocates of more extensive instruments against "social dumping" can be understood. Still, it can reasonably be argued that the Court did no more than interpret the PoW Directive in accordance with the PoW Directive's double objective to create legal certainty for service providers and ensure workers' protection by laying down a nucleus of protective rights that the host Member State must guarantee to all workers carrying out work on its territory. ${ }^{51}$ Interpreting the PoW Directive as allowing

45 See, e.g., Hatzopoulos, V. (2013). Actively talking to each other: the Court and political institutions. In: Dawson, De Witte and Muir, eds., Judicial Activism at the European Court of Justice. Cheltenham: Edward Elgar, pp. 121-122.

46 Laval un Partneri, cit., para. 81. See also Watson, P. (2014). EU Social and Employment Law, cit., p. 299; Feenstra, S. (2009). Detachering van werknemers in het kader van het verrichten van diensten, cit., p. 293 et seq.

47 Court of Justice, judgment of 11 December 2007, case C-438/o5 Viking.

48 Court of Justice, judgment of 3 April 2008, case C-346/o6, Rüffert.

49 Court of Justice, judgment of 19 June 2008, case C-319/o6, Commission v. Luxembourg.

$50 \quad$ These four judgments are also referred to as the "Laval-Quartet". See Malmberg, J. (2010). The Impact of the ECJJudgments on Viking, Laval, Rüffert and Luxembourg on the Practice of Collective Bargaining and the Effectiveness of Social Action. Brussels: European Parliament.

$5^{1}$ For alternative views on the "Laval-Quartet" rulings, see, for example, Davies, A. C. L. (2008). One Step Forward, Two Steps Back? The Viking and Laval Cases in the ECJ. Industrial Law Journal 37 (2), pp. 126-148; Syrpis, P. and Novitz, T. (2008). Economic 
host Member States to impose further-going protective rules would have undermined the effectiveness of the PoW Directive and opened the door to discrimination against service providers exercising their free movement right. ${ }^{52}$

For example, in Rüffert ${ }^{53}$ the Court had to rule on German legislation, which allowed public tenders for construction projects to be awarded only to undertakings committing to pay their employees the minimum wage prescribed by the collective agreement in the place where the service is provided. In the case at hand, a contract with a German undertaking had been terminated when that undertaking's Polish subcontractor turned out to be paying wages below the level indicated in the collective agreement covering the sector. That agreement had however not been declared universally applicable within the meaning of Article 3(1) of the PoW Directive. Neither could the agreement fall within the scope of Article 3(8) of the PoW Directive, which only applies where - unlike in Germany - there is no system to declare collective agreements universally applicable. Therefore, the Court concluded that the rates of pay fixed by the collective agreement in question could not be considered minimum rates of pay and could under the PoW Directive not be imposed on the posting undertaking. ${ }^{54}$ Otherwise, the Court would indeed have allowed the host Member State to impose conditions on posted workers that were not obligatory to local undertakings. In its later RegioPost judgment ${ }^{55}$ the Court made clear that where minimum wage conditions are effectively fixed by law, even only within a region of the host Member State, it is not against the PoW Directive or free movement to require contractors and their subcontractors to respect those conditions. Unlike in Rüffert, the obligation for the employer had in RegioPost also been laid down in a transparent and non-discriminatory manner.

\section{Clarification of the Rules through the Enforcement Directive}

The wage differences that caused posting of workers to increase have unfortunately also led to increased attempts at fraud or circumvention of the rules

and Social Rights in Conflict: Political and Judicial Approaches to Their Reconciliation. European Law Review 33 (3), pp. 411-426, and Barnard, C. (2008). Social Dumping or Dumping Socialism? Cambridge Law Journal 67 (2), pp. 262-264.

52 See also Rosas, A. (2010). Finis Europae socialis?. In: Cohen-Jonathan, Constantinesco, Michel, eds., Chemins d'Europe - Mélanges en honneur de Jean-Paul Jacqué. Paris: Dalloz, p. 591 et seq.

53 Rüffert, cit.

$54 \quad$ Ibid., para. 31.

55 Court of Justice, judgment of 17 November 2015, case C-115/14, RegioPost. 
by undertakings seeking to exploit business opportunities with underpaid workers. Circumvention of the posting rules goes from non-compliance with the labour law or social security regulations, which is left undetected due to limited or vague requirements of cooperation and information exchange for national authorities, all the way to the setting up of "letterbox companies" in a Member State with low-wage levels in order to have work carried out in a high-wage Member State by workers posted from the first Member State. To strengthen the enforcement of the PoW Directive, but also to address the developments in the case law on the right to take collective action (read: Viking and Laval), the Commission started working on two proposals. In March 2012 it proposed a Regulation on the exercise of the right to take collective action (the so-called Monti II proposal) ${ }^{56}$ and a Directive on the enforcement of the PoW Directive, which avoided reopening negotiations on the provisions of the PoW Directive itself. ${ }^{57}$ The first proposal was withdrawn after huge opposition from trade unions and national parliaments making use of the yellow card procedure foreseen in the Subsidiarity Protocol. ${ }^{58}$ The second proposal was adopted in May 2014 by the European Parliament and the Council as Directive 2014/67/EU on the enforcement of Directive 96/71/EC (the "Enforcement Directive"). ${ }^{59}$

In order to prevent abuse and circumvention of the posting rules, the Enforcement Directive calls upon national authorities to assess whether workers posted on their territory are genuinely posted, that is have a genuine employment relationship with the posting undertaking established in the home Member State, which in turn should genuinely perform substantial activities in that home Member State ${ }^{60}$ The host Member State must make information on the terms and conditions imposed on posted workers available free of charge in a clear, transparent, comprehensive and easily accessible way, including on an

$5^{6}$ Proposal of 21 March 2012 for a Council Regulation on the exercise of the right to take collective action within the context of the freedom of establishment and the freedom to provide services, $\mathrm{COM}(2012) 130$ final.

57 Proposal of 21 March 2012 for a Directive of the European Parliament and of the Council on the enforcement of Directive 96/71/EC concerning the posting of workers in the framework of the provision of services, $\operatorname{COM}(2012) 131$ final.

$5^{8}$ See Protocol (No 2 ) on the application of the principles of subsidiarity and proportionality, Art. $7(2)$.

59 Directive 2014/67/EU of the European Parliament and of the Council of 15 May 2014 on the Enforcement of Directive 96/71/EC concerning the posting of workers in the framework of the provision of services and amending Regulation (EU) No 1024/2012 on administrative cooperation through the Internal Market Information System ('the Im I Regulation'), OJ L 159, 28.5.2014, p. 11-31. 
official national website. ${ }^{61}$ The Enforcement Directive further lays down obligations on mutual assistance, cooperation and monitoring and on the crossborder enforcement of administrative penalties and fines. Importantly, the Enforcement Directive also introduced rules on subcontracting. ${ }^{62}$

Revision of the Posting of Workers Directive

The Enforcement Directive laid the ground for improved information of service providers and better enforcement of the protective rules set out in the PoW Directive but did not lead to any changes in these rules. Since the PoW Directive requires posted workers to be guaranteed only minimal rates of pay in the host Member State, posted workers do not necessarily benefit from similar protection in terms of wages as local workers. As indicated above, differences in wage levels have been more marked following the accession of Eastern European Member States. Against that background, the Juncker Commission issued in March 2016 a proposal for a "targeted review" of the PoW Directive (the "2016 Proposal"). ${ }^{63}$ The Commission put forward further clarifications of social security rules in situations of posting in a proposal submitted in December 2016 for a revision of Regulations 883/2004 and 987/2009 on the coordination of social security systems. ${ }^{64}$

\section{V.1 The Commission's 2016 Proposal}

As already announced by Jean-Claude Juncker in July 2014, the Commission's proposal was presented as a "targeted" revision of the PoW Directive in view of ensuring fair working conditions for all workers. The essence of the proposal has been to replace the host Member State's obligation to impose minimum rates of pay by the requirement to have all legislation and collective agreements on remuneration applicable to posted workers, that is to say to have posted workers receiving wages determined in accordance with the same rules as local workers. For that purpose, relevant provisions of collective agreements

\footnotetext{
61 Ibid., Art. 5 .

62 See fn. 100 and accompanying text.

63 Proposal of 16 December 1996 for a Directive amending Directive 96/71/EC of the European Parliament and of the Council concerning the posting of workers in the framework of the provision of services, Сом(2016) 128 final.

64 Proposal of 13 December 2016 for a Regulation of the European Parliament and of the Council amending Regulation (EC) No 883/2004 on the coordination of social security systems and regulation (EC) No 987/2009 laying down the procedure for implementing Regulation (EC) No 883/2004, СOM(2016) 815 final.
} 
declared universally applicable should be applied also outside the construction sector. ${ }^{65}$ Guaranteeing the principle of "equal pay for equal work at the same place" not only aims at ensuring adequate protection of workers' rights, but also at strengthening the legitimacy of the internal market by ensuring fairness in the market. Since so-called social dumping can lead to the downgrade of existing labour rights and wage levels, the initiative also aimed at preventing distortion of national labour markets and promoting upwards social convergence.

Since it had already been difficult in 1991 to convince the Member States of the need to introduce rules for posted workers, it came as no surprise that in a Union with twice as many Member States, the appetite for another change of the rules applied to posted workers was not universally shared. Applying the Subsidiarity Protocol, fourteen parliamentary chambers from eleven mostly Eastern European Member States ${ }^{66}$ issued reasoned opinions alleging that the revision would breach the principle of subsidiarity. Arguing that wage differences constitute a legitimate factor for competition between service providers, they considered the principle of equal pay for equal work at the same place to violate the Treaty provisions on the internal market. Again, the parliaments collected sufficient negative opinions to trigger the "yellow card" procedure, requiring the Commission to review its proposal. In its response, ${ }^{67}$ the Commission pointed out that the proposal was not in breach of subsidiarity since posting of workers is by nature a cross-border so that an obligation to apply rules in all the Member States and across sectors could only be established at Union level. In the Commission's view, its proposal also remains in line with the spirit of the internal market as applying the same mandatory rules to all workers performing work at the same place also ensures undertakings to be subject to the same rules across the Union.

Since the Commission did not amend or withdraw its proposal, the legislative discussions on the 2016 Proposal could start, both in the Council, under successive Presidencies, and in the European Parliament, within its Employment Committee. Early 2017, an agreement in the Council seemed within reach until certain Member States hardened their position, including France (following President Macron's election), but also other Member States

65 See also below for the situations under which certain agreements that have not been declared universally applicable may be taken into account.

66 Negative opinions came from Denmark and 10 Central and Eastern European Member States (Bulgaria, Croatia, Czech Republic, Estonia, Hungary, Latvia, Lithuania, Poland, Romania and the Slovak Republic).

67 Communication Сом(2016) 505 final of 27 July 2016 from the Commission on the posting of workers Directive, with regard to the principle of subsidiarity. 
expressing discontent with the proposals on specific rules for posting in the road transport sector that the Commission tabled end May 2017. ${ }^{68}$ By October 2017, however, the way had been paved for each of the co-legislators to find agreement on a position on the basis of which interinstitutional negotiations could start: the Council in a general approach adopted late-night after a memorable discussion on 23 October 2017 in the Employment and Social Affairs Council, ${ }^{69}$ the Parliament's Employment Committee with the adoption on 16 October 2017 of a report prepared by the two co-rapporteurs. ${ }^{70}$ Importantly, these provisional agreements also received support in several Eastern European Member States, ${ }^{71}$ attesting to the balance struck between the interests of enhancing workers protection and preserving free movement opportunities.

Under the Estonian and then the Bulgarian Presidency of the Council, the negotiators of the European Parliament, the Council and the Commission met in eight "trilogue" sessions, the Commission being represented by the Commissioner for Employment, Social Affairs, Skills and Labour Mobility, Marianne Thyssen, who had initiated the revision in 2016. After a breakthrough on the main political issues in the early hours of 1 March 2018, a provisional agreement was reached on 19 March 2018 on the full text of the Directive revising the PoW Directive (referred to hereinafter as the "Revising Directive"72; the amended provisions of the PoW Directive are referred to as the "Revised PoW Directive"). Crucial for reaching that final agreement was the fact that the Revising Directive will only become applicable to the sector of road transport once the proposed specific rules for posting in that sector have been adopted and become applicable. ${ }^{73}$ Following the endorsement of that provisional agreement in the

68 Proposal of 31 May 2017 for a Directive of the European Parliament and of the Council amending Directive 2006/22/EC as regards enforcement requirements and laying down specific rules with respect to Directive 96/71/EC and Directive 2014/67/EU for posting drivers in the road transport sector, $\operatorname{com}(2017) 278$ final. At the time of writing, the political agreement reached on this proposal in December 2019 still had to be formally approved by the European Parliament and the Council, see fn. 26 supra.

69 General approach agreed by the Employment, Social Policy, Health and Consumer Affairs Council on 23 October 2017, Council doc. 13612/17 of 24.10.2017.

70 Report of the Committee on Employment and Social Affairs, doc. A8-o319/2017 of 19 October 2017 (Rapporteurs: Elisabeth Morin-Chartier and Agnes Jongerius).

71 Bulgaria, the Czech Republic, Estonia, Romania and the Slovak Republic voted in favour in the October Council, whereas Croatia (together with Ireland and the UK) abstained and only Hungary, Latvia, Lithuania and Poland voted against. Pursuant to Art. 53 TFEU, the ordinary legislative procedure applied, in which the Council votes by qualified majority.

72 Directive 2018/957, cit.

73 See Revising Directive, Art. 3(3). The review that the Commission must undertake within 5 years of the Revising Directive's entry into force will include an assessment of the 
European Parliament on 29 May 2018 and in the Council on 21 June 2018 - with even broader geographical support than the negotiation mandates ${ }^{74}$ - the PoW Directive was adopted on 28 June 2018. Meanwhile, Hungary and Poland have sought the annulment of the Revised PoW Directive, considering that the protection granted to workers exceeds what is possible under the Treaty provisions on free movement of services. ${ }^{75}$ This legal challenge does not suspend the application of the PoW Directive, which will apply as from 30 July $2020 .{ }^{76}$ As set out below, this contribution argues that the Revised PoW Directive has duly remained within the boundaries of its legal basis and does not conflict with the Treaty provisions on free movement.

\section{V.2 Revised Rules for the Posting of Workers}

Besides replacing the requirement to pay posted workers at least "minimum rates of pay" by the requirement of having posted workers' wages completely defined in accordance with the host Member State's laws and (universally applicable) collective agreements, the 2016 Proposal also put forward a higher level of protection for workers posted for a long-term period, defined as any period exceeding the 24 months period during which workers remain covered by the social security legislation of the home Member State. In addition, the Commission proposed allowing Member States to extend the Directive's requirements on wages to workers employed in subcontracting. In the course of the legislative discussions, those issues have been intensively debated while new issues were put on the table, such as the clarification of the status of posting allowances and collective agreements, guarantees of enforcement with respect to certain categories of posted workers, the conditions under which the posting rules would become applicable to the road transport sector and the general conditions for transposition and entry into force of the proposed Directive. Interestingly, the European Parliament initially also requested to have the objective of increased workers protection reflected in the legal basis of the

need for further measures in the light of developments concerning this "lex specialis" (for example, in case the legislative negotiations on that "lex specialis" would not yet have been successful). Ibid., Art. 2(2). For all other sectors, the Revising Directive will be applicable in all Member States at the expiry of the two year transposition period. Ibid., Art. 3(1).

74 Compared to the vote in Council of October 2017 (see fn. 71), at the June 2018 meeting of the Council just Hungary and Poland voted against, with only Croatia, Latvia, Lithuania and the UK abstaining.

75 Case C-620/18 Hungary v European Parliament and Council (see OJ C 428, 26.11.2018, p. 31) and case C-626/18 Poland v European Parliament and Council (see OJ C 4, 07.01.2019, p. 12). Revising Directive, Art. 4. 
proposed Directive, which, in its view, had to be considered not merely as the implementation of free movement provisions but also as pursuing social policy. However, as explained below, the increase in workers protection resulting from the revision has remained within the internal market legal basis of the initial PoW Directive.

\section{V.3 Remuneration, Posting Allowances and Collective Agreements}

As indicated above, the essential change of the revision has been to change the notion of "minimum rates of pay" applicable to posted workers under Article $3(1)(c)$ of the PoW Directive to the notion of "remuneration", defined as "all the constituent elements of remuneration rendered mandatory by national law, regulation or administrative provisions, or by collective agreements or arbitration awards, which, in that Member State, have been declared universally applicable". With the revised Article $3(1)$ (c) the nucleus of rights guaranteed to posted workers therefore includes all the elements of remuneration as defined in the host Member State, and not only minimum rates of pay. Whereas this provision eliminates wage competition between posted workers and local workers, it will lead to a wage increase for workers posted to high-wage Member States. By reducing the risk of unfair competition based on low working conditions, the Revised Directive also ensures a "level playing field" for all businesses concerned. All in all, the revision therefore does not change the character of the PoW Directive as an instrument ensuring legal certainty for cross-border service providers, but it increases the level of ambition of that instrument from a social perspective, going from requiring employers to guarantee a minimum level of protection of posted workers to a requirement to make posted workers benefit from the same rules on wages that apply to other workers carrying out the same kind of work.

Clearly, the proposed provision on "remuneration" does not align the levels of wages across the Member States, which is an area that the Treaty expressly excludes from the Union's harmonisation powers in social matters. ${ }^{77}$ During the legislative discussions, both the European Parliament and the Council had no difficulty in accepting the notion of "remuneration", not however without emphasizing in the agreed text that setting rules on remuneration and wages remains an exclusive competence of the Member States and social partners. ${ }^{78}$ Wages of posted workers will still be set by their employment contract, which is usually concluded under the law of the home Member State, and workers'

77 Art. 153(5) TFEU, according to which the powers set out in this Article do not apply to pay.

78 Revising Directive, recital 17. 
salaries may therefore still differ, depending on the rules and practices of the Member States in question and of their employer. Still, once the Revised Directive applies, employers will have to pay their posted workers not only by complying with the rules on remuneration of the law applicable to the employment contract (home Member State legislation) but also by ensuring that the remuneration paid during the posting assignment is at least equivalent to the remuneration that worker would be entitled to under the relevant legislation and collective agreements of the host Member State. Upon the Council's request, the preamble to the Revised Directive clarifies how to assess the compatibility of the salary paid under the home Member State's rules with the elements of remuneration set by the host Member State's rules. In line with the Court's case law on minimum pay, ${ }^{79}$ the posted worker's gross salary will need to be matched up to the gross amounts of pay required by the rules on "remuneration" rather than to individual elements of remuneration required by the host Member State. ${ }^{80}$ As under the existing rules, ${ }^{81}$ allowances specific to the posting should be considered part of the remuneration, unless they compensate for expenditure actually incurred on account of the posting, such as expenditure on travel, board and lodging. ${ }^{82}$ If, for example, the relevant collective agreement in the host Member State requires the posted worker to be paid a monthly salary of 1500 EUR and daily allowances of 300 EUR, whereas that worker is, under home Member State rules, entitled to a salary of 500 EUR but also to a seniority allowance and a flat-rate posting allowance of 100 EUR and 1200 EUR, respectively, it is the gross amount of 1800 EUR paid to the worker under home Member State rules that must be compared with the gross amount of remuneration required under the host Member State rules (also 1800 EUR in the example).

By having posted workers benefit from the elements of "remuneration" applicable to local workers in the host Member State - translated politically as the principle of equal pay for equal work at the same workplace - the Revising Directive is likely to increase salaries for posted workers, especially those posted from lower-wage Member States to higher-wage Member States. During the legislative discussions, both the European Parliament and the Council also insisted on introducing amendments and clarifications on what constitutes remuneration and on the precise status of allowances paid on the top of salaries. The sensitivity of the issue of allowances may be explained, to a certain extent,

79 Commission v. Germany, cit., para. 29.

8o Revising Directive, recital 18.

81 PoW Directive, Art. 3(7).

82 Revising Directive, recital 18. 
by the phenomenon of posting undertakings seeking to increase their competitive advantage by paying lower social contributions and/or taxes and, for that purpose, preferring to pay their workers relatively low salaries supplemented with high allowances. To the extent that posting allowances do not concern expenditure actually incurred, they do qualify as remuneration for the purpose of the host Member State rules. This does not mean that the host Member State determines whether such allowances must be paid. It is indeed for the law or collective agreements of the home Member State to determine whether such allowances are to be paid at all, together with the amount of such allowances. In order to ensure that posting allowances taken into account for the purposes of remuneration under host Member State rules genuinely constitute part of the workers' remuneration, and not compensation for incurred expenditure, an amendment from the Council has been adopted according to which posting allowances are presumed to be compensation for expenditure actually incurred. Indeed, for an allowance to be considered part of remuneration, this must clearly result from the terms and conditions applicable to the employment relationship. ${ }^{83}$ If the parts of the allowance constituting either reimbursement or remuneration are not defined in the applicable legislation, collective agreement or contractual arrangements, the entire allowance will be considered to be paid in reimbursement. ${ }^{84}$

Concerning allowances that constitute reimbursement of expenditure, the co-legislators added two more elements in the Revising Directive. First, upon a request from the Council, the nucleus of protective rights in Article 3(1) of the PoW Directive is complemented with a reference to allowances reimbursing travel, board and lodging expenditure incurred by posted workers that have to travel to and from their regular place of work within the host Member State. ${ }^{85}$ In the above-mentioned Finnish case, the Court of Justice had already clarified that where a host Member State requires such posting allowances to be paid, they are part of the minimum wage that under the PoW Directive must be paid to local workers and posted workers alike. ${ }^{86}$ This will now also be the case for the application of the notion of "remuneration". It has also been clarified that all this should not lead to posted workers receiving double payment for the same expenses. ${ }^{87}$ Second, with respect to all allowances reimbursing expenditure for travel, board or lodging, the Revising Directive confirms the

83 Revised PoW Directive, Art. 3(7), new third subparagraph.

84 See also Revising Directive, recital 19.

85 See Revised PoW Directive, Art. 3(1)(i).

86 See supra fn. 30 and accompanying text.

87 Revising Directive, recital 9 (requested by the European Parliament). 
employers' obligation to reimburse the workers for the expenditure incurred, in accordance with the national law applicable to the employment relationship, which is normally the home Member State law. ${ }^{88}$ This confirmation has been requested by the European Parliament. ${ }^{89}$

Regarding the nucleus of protective rights, it should also be mentioned that a request of the Council has been accepted to also include in Article 3(1) of the PoW Directive the "conditions of workers' accommodation where provided by the employer to workers away from their regular place of work". ${ }^{90}$

In the Commission's proposal, posted workers' rights were to be increased not only by imposing the host Member State's rules on "remuneration", but also by making wage and working conditions laid down in collective labour agreements applicable. Under the existing PoW Directive, that was already the case in the construction sector, but not in other sectors. The Commission's proposal left the conditions unchanged allowing collective agreements to be applicable, that is to say only those agreements which have been declared universally applicable or, in the absence of a system for declaring agreements universally applicable, those which are generally applicable in the geographical area or in the industry concerned. ${ }^{91}$ In order to avoid discrimination between local and posted workers, Article $3(8)$ of the PoW Directive allows for the application of collective agreements in a Member State where no system of declaring agreements universally applicable exists (read: Sweden) only if equality of treatment is ensured in their application. The European Parliament insisted that also working conditions set out in non-universally applicable collective agreements should be applied to posted workers. This would have allowed for the reversal of the Court's ruling in the above-mentioned Rüffert case, where the Court did not allow Germany to impose minimum rates of pay set out in an agreement that was not declared universally applicable. ${ }^{92}$ Eventually, the colegislators agreed to slightly extend the conditions set out in Article $3(8)$ to collective agreements that have not been declared universally applicable, so that, even in a Member State where that possibility exists, collective agreements that have not been declared universally applicable can be applied to posted workers falling within their sectorial or geographical scope of application, but

88 See Revised PoW Directive, Art. 3(7), second subparagraph.

89 Initially, the European Parliament proposed language that remained unclear as to the basis for the obligation to reimburse, leaving it open whether the host Member State could introduce such obligation (see amendment 32 of the Report, supra fn. 70).

9o See Revised PoW Directive, Art. 3(1)(h).

91 PoW Directive, Art. 3(1) and (8).

92 Supra supra fn. 54 and accompanying text. 
still only if the conditions of equal treatment set out in Article $3(8)$ are fulfilled. ${ }^{93}$

It follows that, although the Commission's proposal already provided for increased protection of workers, the co-legislators accepted further provisions that are even more beneficial for the posted workers, while also introducing more clarity and transparency.

\section{V.4 Long Term Posting}

Whereas the PoW Directive states that posting of workers is of a temporary nature, it does not clarify the notion "temporary". In Regulation (EC) No 883/ 2004 on the coordination of social security systems, workers posted from a Member State for a period longer than 24 months are considered no longer having the required link with that Member State to be subject to that Member State's legislation for the purposes of social security coverage. By reference to that rule, the Commission had proposed to consider workers posted for longer than 24 months as falling under the host Member State's legislation for the purposes of determining their working conditions. ${ }^{94}$ This alignment would have provided full legal clarity to the workers, the employers and the authorities.

During the legislative discussions, the Council agreed with the principle of having long-term postings made subject to the labour law of the host Member State, with exceptions as regards application of the rules on the conclusion and termination of contracts and on contributions for supplementary pension schemes. That text made it into the final agreement of the co-legislators. ${ }^{95}$ However, the actual duration of the period triggering the change in regime has been the source of fierce debates, particularly because that period has been communicated by many governments and stakeholders as a maximum period that would prohibit longer posting assignments instead of being a trigger towards a (slightly) different legal regime. ${ }^{96}$ In the 2016 campaign for the French

93 See the changes in Revised PoW Directive, Art. 3(1) and (8).

94 The 2016 Proposal considered that, in case of an anticipated or effective duration of the posting exceeding 24 months, the worker should be deemed to habitually carry out its work in that Member State, which is the default connecting factor to determine the law applicable to an employment relationship. See Art. 8 of Regulation (EC) No 593/2008 of 17 June 2008 on the law applicable to contractual obligations (Rome I), OJ L 177, 4.7.2008, p. $6-16$.

95 See Revised PoW Directive, Art. 3(1a). The co-legislators also changed the Commission proposal so as to take account only of the effective duration of a posting assignment, not its anticipated duration, which probably would have been difficult to monitor.

96 Given the extensive list of areas already covered by the nucleus of protective rights applicable to posted workers pursuant to Art. 3(1) of the PoW Directive, the areas of labour law 
presidency, Emmanuel Macron thus defended the need for a maximum period of 12 months. Following long and difficult discussions, the Council eventually agreed on 23 October 2017 to lower the 24 months threshold proposed by the Commission to 12 months, with an extension of 6 months to be granted to service providers submitting a "motivated notification" to the host Member State authorities. At the same time, the European Parliament had agreed to keep the Commission's reference to 24 months, while allowing for an extension of that period, but only upon assessment by the authorities of a reasoned request thereto. That amendment relied on the consideration that although the average duration of posting assignments does not exceed 4 months, high skilled professionals are sometimes seconded for longer periods than two years, so that lowering the threshold would create unreasonable burden for that kind of posting assignments. Eventually, the co-legislators agreed to keep the reference for the long-term posting at 12 months, with a quasi-automatic extension of 6 months upon a "motivated notification" by the service provider. In order to emphasize that Member States cannot prohibit posting assignments longer than 12 (or 18) months, a recital has been inserted which reminds the Member States that any measure restricting such posting assignments must be compatible with the freedom to provide services. ${ }^{97}$

\section{V.5 Abuse and Strengthened Enforcement of the Posting of Workers Directive}

Given the strengthened framework laid down in the 2014 Enforcement Directive, the 2016 Proposal did not as such tackle issues of enforcement of the posting rules. It however included a provision on subcontracting since posting of workers through subcontracting chains is often used to circumvent posting rules.

The system whereby a principal contractor outsources tasks or activities to other companies or self-employed workers is a common business model across the Union, especially in sectors like construction and road transport, where there is also a high involvement of posted workers. The Commission estimated that in the construction sector, in 2011, payments by undertakings to subcontractors ranged between less than 15 per cent (in Romania, Poland, Portugal, Italy and Denmark) to over 3 o per cent (Slovakia, Czech Republic and the UK) of turnover. ${ }^{98}$ In a cross-border subcontracting chain, an undertaking providing

for which long-term posted workers would see a shift in applicable law is indeed limited (for example, entitlements to leaves, such as parental leave, not included in Art. 3(1)(b)).

97 Revising Directive, recital 10.

98 See Commission Staff Working Document - Impact Assessment accompanying the 2016 Proposal, $\operatorname{swD}(2016) 52$ final, point 2.4.1. 
services may outsource an activity to another company to which workers are posted from another Member State or directly to a subcontractor established in another Member State. In a context of weak cooperation between national authorities in matters of social security and labour law, subcontracting may be instrumental in organising circumvention of rules and fraud. ${ }^{99}$ The PoW Directive does not contain specific rules for subcontracting chains, leaving certain posted workers in sub-contracting chains in a situation of particular vulnerability. The 2014 Enforcement Directive covered the gap in subcontractors' liability by providing a legal framework for posted workers to hold the undertaking that subcontracted with their employer liable for any outstanding payments. ${ }^{100}$ Still, it only provided for joint liability in direct subcontracting situations, without ensuring protection of posted workers throughout the entire subcontracting chain. It indicated however that Member States may adopt further going measures if that is done on a non-discriminatory and proportionate basis. ${ }^{101}$

To better protect posted workers in subcontracting situations, the Commission had proposed to broaden the possibility for Member States to regulate subcontracting. The Proposal provided that, whenever a host Member State requires undertakings to subcontract only to companies that guarantee certain terms and conditions of employment covering remuneration, that Member State could extend such obligation also to undertakings subcontracting with companies established in another Member State that post workers to the host Member State. The proposed provision only contained a possibility, not an obligation for Member States to extend workers' protection to subcontracting involving posted workers. However, it did not receive any support in the Council and, even though the Parliament supported it, the widespread opposition amongst the Member States made it impossible for the co-legislators to introduce any obligation for subcontractors to follow the rules on remuneration. As a matter of compromise, the co-legislators agreed that in the context of a future revision of the Directive, the Commission is to assess whether further measures in subcontracting are needed to ensure workers' protection and a level playing field for businesses. ${ }^{102}$

In its Proposal, the Commission also tackled another situation in which posting of workers is prone to abuse, that is posting of workers by temporary

99 See, for example, Court of Justice, judgment of 6 February 2018, case C-359/16, Altun and Others.

100 Enforcement Directive, Art. 12.

101 See Enforcement Directive, recital 36, in fine.

102 Revising Directive, Art. 2(2). 
work or placement agencies, which hire out workers to user undertakings established or operating in another Member State. The PoW Directive also applies to such posted workers, subjecting them to the host Member State's minimum rates of pay and other working conditions set out in Article 3(1). Article 3(9) of the PoW Directive also goes further by allowing Member States to provide that temporary agency workers posted on their territory must be fully subject to the same working conditions as local temporary workers. In the 2016 Proposal, the Commission suggested to make this option obligatory, in line with Article 5 of the Temporary Agency Work Directive, ${ }^{103}$ which already establishes the obligation for a user undertaking to grant domestic temporary workers the same basic working and employment conditions as permanent workers in the same job. The co-legislators agreed with this proposal, ${ }^{104}$ so that, with respect to the basic working and employment conditions set out in the Temporary Agency Work Directive, posted workers are to be guaranteed equal treatment with local workers. Moreover, the co-legislators added an optional clause according to which Member States may ensure posted temporary workers also equal treatment with respect to the other working and employment conditions. ${ }^{105}$ All this does not only improve the situation of the workers concerned, but also ensures a level-playing field for the agencies concerned. Through this equal treatment clause, posted temporary workers may actually benefit from provisions in collective agreements that would otherwise not be applicable to them, for example, collective agreements concluded only at company level or sectorial agreements that have not been declared universally applicable, thereby going beyond the more circumscribed application foreseen for collective agreements under Article $3(8)$ of the Revised PoW Directive. ${ }^{106}$

The co-legislators added the obligation for the user undertaking to inform the temporary work agencies of the terms and conditions applied by it. ${ }^{107}$

Another issue related to the temporary working agencies, is so called "double" or "chain" posting, which occurs when a worker posted by an agency to a user undertaking in a host Member State, is then asked by that user undertaking to carry out work in a third Member State. This situation often creates legal uncertainty as, first, the agency is not always informed of the "double" posting, and, second, national authorities have difficulties in determining the rights on

103 Directive 2008/104/EC of the European Parliament and of the Council of 19 November 2008 on temporary agency work, $O J L$ 327, 5.12.2008, p. 9-14.

104 Revised PoW Directive, Art. 3(lb).

105 See Revised PoW Directive, Art. 3(9).

106 See supra fn. 93 and accompanying text.

107 Revised PoW Directive, Art. 3(1b). See also Revising Directive, recital 12. 
remuneration and working conditions applicable to such worker. Since Article 1(3) of the PoW Directive requires the existence of an employment relationship between the undertaking making the posting and the posted worker during the whole period of posting, it could be argued that the "second" sending abroad of the worker is not "genuine" and should not be considered to be posting within the meaning of the Directive. The question then arises, however, which working conditions are applicable to that worker in the third Member State. Building upon amendments suggested by the European Parliament, the co-legislators agreed to provide that in such a situation of double posting it must be considered that the worker is posted in the third Member State and that the temporary agency is the posting undertaking responsible for guaranteeing that worker the rights to which he or she is entitled under the PoW Directive and the Enforcement Directive. ${ }^{108}$ In order to make that rule enforceable, a provision has been added according to which the user undertaking must inform the temporary agency of posted workers that will be temporarily carrying out work in a Member State other than the one to which they have been posted. These provisions will make a real difference on the ground by clarifying the application of the posting rules in situations currently in a "grey zone". By making the temporary agency as employer responsible for any subsequent posting, the PoW Directive will contribute to preventing circumvention of rules through chain posting of temporary workers.

In addition to these changes regarding temporary agency workers and chain posting, the Revised Directive also contains strengthened rules on access to information and fighting fraud and abuse in situations of nongenuine posting. As indicated above, the Enforcement Directive already establishes an obligation for a host Member State to ensure that information on the applicable terms and conditions of employment is made generally available in a transparent way. The co-legislators agreed that the host Member State's authorities must publish on the official website foreseen in the Enforcement Directive accurate and up to date information on the constituent elements of remuneration. ${ }^{109}$ Upon request of the European Parliament, a provision was added to ensure that workers that are not genuinely posted are not left without any protection. The difficulty of such provision is that workers which are found not to be in a situation covered by the PoW Directive may, for example, be permanently employed in a host Member State instead of temporarily posted, or self-employed. Article 4 of the Enforcement

108 Revised PoW Directive, Art. 1(3), new second and third subparagraphs.

109 See Revised PoW Directive, Art. 3(1), new third to fifth subparagraphs. 
Directive already provides the Member States with criteria for assessing whether the relationship between an undertaking and a worker is a genuine employment relationship. The co-legislators eventually agreed that in a situation where after such assessment by the host Member State it is established that an undertaking is improperly or fraudulently creating the impression that a worker is posted in accordance with the PoW Directive, that Member State shall ensure that the worker benefits from "relevant law and practice" and not be subject to "less favourable conditions than those applicable to posted workers". ${ }^{110}$ Whereas this provision does not clearly indicate which conditions should be applied to a worker who, by definition, falls outside the scope of the PoW Directive, it nonetheless requires Member States to ensure that such workers do not stay in a disadvantaged situation as compared to posted workers.

As posting of workers is by definition a transnational issue, certain cases of circumvention and abuses may remain undetected or not penalised due to lack of cooperation and adequate information exchange between the competent authorities of the Member State concerned. The PoW Directive already created in Article 4(1) an obligation for the Member States to provide for cooperation between public authorities and to share information in fighting unlawful and abusive transnational activities. The Enforcement Directive further developed these cooperation requirements. Also the Commission's proposal on revision of the Regulations on social security coordination provides for a strengthening of the requirements on information exchange and verification of the socials security status of posted workers to prevent unfair practices or abuse. ${ }^{111} \mathrm{To}$ enhance cooperation and ensure better enforcement of cross-border mobility situations, the Commission submitted on 13 March 2018 a proposal for establishing a European Labour Authority (ELA), ${ }^{112}$ which Commissioner Thyssen managed to have adopted by the European Parliament and the Council before the 2019 European elections. ${ }^{113}$ Although this agency is meant to facilitate cooperation between the Member States' enforcement authorities in all areas of labour mobility and social security coordination, its expertise and network should certainly ensure enhanced enforcement of the posting rules, more

\footnotetext{
110 Revised PoW Directive, Art. 5, fourth and fifth subparagraph.

111 See the proposed revision of Arts 5, 14, 16 and 19 of Regulation 987/2009, cit.

112 Proposal of 13 March 2018 for a Regulation of the European Parliament and of the Council establishing a European Labour Authority, $\operatorname{COM}(2018) 131$ final.

113 Regulation (EU) 2019/1149 of the European Parliament and of the Council of 20 June 2019 establishing a European Labour Authority, amending Regulations (EC) No 883/2004, (EU) No 492/2011, and (EU) 2016/589 and repealing Decision (EU) 2016/344, OJ L 186, 11.7.2019, p. $21-56$.
} 
intense cooperation between the competent national authorities through liaison officers working within the Authority and eventually stronger protection of posted workers against abuses and fraud. ${ }^{114}$ Cooperation at Union level between the authorities responsible for labour law and social security issues is essential to guarantee proper enforcement of the existing rules and prevent fraud and abuse.

Given its relevance for the situation of posted workers, it is unfortunate that the co-legislators have not been able to finalise the revision of the social security coordination Regulation before the 2019 elections. In March 2019, the negotiators for the Council and the European Parliament reached a compromise agreement, which was supported in the Council by a coalition of Eastern European and Mediterranean states but eventually did not obtain the required qualified majority to be formally adopted. ${ }^{115}$ Likewise, a political agreement on the proposed reform of road transport rules could not be reached before the elections, but only in December 2019 - a file in which the opposition of interests between "sending" and "receiving" Member States has been exacerbated by differences between centrally located and more peripheral Member States. ${ }^{116}$ The sensitivity of these two other labour mobility files demonstrates the difficulties that the Juncker Commission surpassed when reaching agreements on the Revised PoW Directive and the European Labour Authority. As regards the ELA - for which the founding Regulation has been adopted within a very short period of time - it is important to note that the Commission deliberately avoided to reduce it to an enforcement tool for 'receiving' Member States focused on combating breaches of EU rules by foreign employers. ${ }^{117} \mathrm{The}$

114 See Van Nuffel, P. (2019). De Europese Arbeidsautoriteit: een nieuw agentschap voor eerlijke arbeidsmobiliteit binnen de interne markt. In: Verschueren, ed., Detachering - Nieuwe ontwikkelingen in het Europees recht vanuit Belgisch en Nederlands perspectief. Brugge: Die Keure, pp. 227-258.

115 On 21 June 2018, the Council approved a negotiating mandate ("general approach") whereby only Austria, Belgium, Cyprus, Denmark, Germany, Luxembourg, Malta and the Netherlands voted against or abstained. After the European Parliament also approved a negotiating agreement, the negotiators of the Parliament, the Council and the Commission reached a provisional agreement on 19 March 2019, for which however there was no qualified majority among Member States on 29 March 2019 when, in addition to the aforementioned Member States, the Czech Republic, Hungary, Poland and Sweden also indicated that they could not support the agreement. The European Parliament decided at its last plenary session on 18 April 2019 not to vote on the provisional agreement.

116 The Council and the European Parliament had adopted a negotiating position on this file on 4 December 2018 and 4 April 2019 respectively, and found an agreement on 12 December 2019, see fn. 26 supra.

117 See Van Nuffel, P. (2019). De Europese Arbeidsautoriteit, cit. 
Commission rather sought to market the ELA as an agency whose first task is to support, guide and inform employers and employees about their rights and obligations in cross-border situations, including by making the ELA responsible for promoting cross-border employment and coordinating the existing European network of employment services (EURES). ${ }^{118}$ The ELA should thus support rather than restrict cross-border services and labour mobility in the internal market. The ELA will in addition provide national enforcement authorities with a range of tools to facilitate the application of EU legislation in situations of cross-border labour mobility. As follows from its mandate, those situations includes posting of workers but also free movement of workers and the coordination of social security systems - thereby essentially ensuring the social protection of all mobile citizens across the Union.

\section{Conclusion}

The PoW Directive remains a delicate piece of legislation as it constitutes a compromise struck between the conflicting interests behind opening up the internal market and safeguarding national protective social standards. It remains therefore a significant achievement that a revision of that Directive has been agreed upon without unduly sharpening the divisions between lowerwage and higher-wage Member States and with express support from many low-wage Member States.

Towards those who advocate that the Revised PoW Directive should have been transformed into a social policy instrument based on the Treaty's social policy legal basis, it must be stressed that the fact that the PoW Directive also promotes the internal market and free movement should not be perceived as making workers' rights subordinate to economic interests. It is true that the Court of Justice, when interpreting the PoW Directive, has found several national measures aimed at protecting workers' rights to be contrary to the PoW Directive. However, the Court has been interpreting the available legal texts in the light of the Treaty provisions, with the principles of non-discrimination and proportionality as guiding values. Moreover, the Court has equally recognised that the social goals pursued by the PoW Directive are not only the protection of posted workers' rights, but also the preservation of fair labour markets and combating social dumping,,19 implying that social rights of local workers and,

\footnotetext{
118 See Regulation 2019/1149, Art. 2.

119 See supra fn. 37 and accompanying text.
} 
more generally, the preservation of Member States' social protection systems are to be taken into account as well. Together with the Enforcement Directive, the Revised PoW Directive has now stepped up the level of social protection by introducing the principle of equal pay for equal work in the same place, while still attaining the objective of preserving legal certainty for undertakings providing services in the internal market. Time will show how the provisions of the Revised PoW Directive will be interpreted, but the stronger social dimension will not be left unnoticed.

As indicated, the 2016 revision of the PoW Directive must be seen in the larger framework of the Juncker Commission's ambitions for ensuring fairer labour mobility, which also included the proposed reform of the Regulations on social security coordination, the "lex specialis" on the application of the posting rules on the road transport sector and the establishment of the ELA. Compared to the initial hostile reactions that the 2016 Proposal received, there is now broad acceptance, also in many low-wage Member States, that stepping up the social protection of posted workers is not an expression of economic protectionism, but a change necessary for the internal market to preserve its social legitimacy. The conditions imposed by the PoW Directive to cross-border service providers are also in line with changes made by the Lisbon Treaty to certain parameters in the Treaty framework with the recognition of the legally binding nature of the Charter of Fundamental Rights, including its Article 31 on fair and just working conditions, and the introduction of Article $9 \mathrm{TEU}$, according to which the Union is to take the requirement of adequate social protection into account in defining and implementing its policies and activities. These changes reflect the understanding that economic growth and liberalisation must go hand in hand with adequate social protection. The same understanding led the European Parliament and the Council to accept in November 2017 the Commission's call for a joint proclamation of a European Pillar of Social Rights, ${ }^{120}$ which constitutes a political confirmation of the recognition of the need for upward social convergence across the Union. The European Pillar of Social Rights is indeed based on the understanding that economic and social progress go hand-in-hand and that upward social convergence in the Union is not opposed to, but rather dependent on the further development of the internal market, the modernisation of labour markets and the enhanced sustainability of social security

120 For the text, see https://ec.europa.eu/commission/sites/beta-political/files/social-summiteuropean-pillar-social-rights-booklet_en.pdf. 
systems. It is against this background that, as Jean-Claude Juncker indicated when announcing the reform of the Pow Directive, ${ }^{121}$ free movement should be seen as an economic opportunity, and not as a threat, and that labour mobility should be promoted, especially where there are persistent vacancies and skills mismatches.

121 See Juncker, J-C (2014). A New Start for Europe, cit. 